\title{
MENINGKATKAN KEMAMPUAN BERPIKIR KREATIF DAN DISPOSISI MATEMATIK SISWA MADRASAH TSANAWIYAH MELALUI PEMBELAJARAN GENERATIF
}

Oleh:

\author{
Hamdan Sugilar \\ Pendidikan Matematika Universitas Suryakancana Cianjur \\ hasugiemath@yahoo.co.id
}

\begin{abstract}
Penelitian ini merupakan penelitian kuasi eksperimen dengan disain kelompok kontrol tidak ekivalen karena tidak adanya pengacakan dalam menentukan subjek penelitian. Peneliti tidak membentuk kelas baru berdasarkan pemilihan sampel secara acak. Subjek sampel diambil dua kelas dari kelas VII siswa MTs Negeri Cikembar Kabupaten Sukabumi, satu kelas sebagai kelas eksperimen dengan pembelajaran generatif dan satu kelas sebagai kelas kontrol dengan pembelajaran konvensional. Instrumen yang digunakan adalah tes dan non tes. Hasil studi penelitian ini adalah: 1) peningkatan kemampuan berpikir kreatif siswa yang mengikuti pembelajaran generatif lebih baik daripada siswa yang mengikuti pembelajaran matematika secara konvensional ditinjau dari pencapaian hasil belajar dan peningkatan kemampuan berpikir kreatif. Kemampuan berpikir kreatif kelas eksperimen termasuk pada kategori sedang sedangkan kelas kontrol termasuk kategori rendah.2) terdapat perbedaan peningkatan kemampuan berpikir kreatif matematik antara siswa kemampuan tinggi, sedang, dan rendah yang mendapat pembelajaran generatif, 3) disposisi matematik siswa yang mengikuti pembelajaran matematika melalui pembelajaran generatif lebih baik daripada siswa yang mengikuti pembelajaran matematika secara konvensional, disposisi matematik siswa pada kelas eksperimen termasuk pada kategori sedang, sedangkan pada kelas kontrol disposisi matematik termasuk pada kategori rendah. 4) terdapat interaksi antara model pembelajaran dan tingkat kemampuan awal siswa dalam menghasilkan kemampuan berpikir kreatif. 5) terdapat asosiasi antara kemampuan berpikir kreatif matematik dengan disposisi matematik, kategori asosiasinya tinggi.
\end{abstract}

Kata Kunci : Pembelajaran Generatif, Berpikir Kreatif, Disposisi Matematik

This research quasi-experiment with design controls not equivalent as there is not a beating in determining the subject research. Researchers does not set up new class based on the election samples randomly. The subject samples taken two classes of class VII students MTs Cikembar Sukabumi, a class as class experiment with learning generative and one class as control classes with conventional teaching. Instruments that used is testing and non-test. Result of the study this research are: 1) increase the capacity and capability creative thinking students attending generative learning better than students who follow in mathematics teaching conventional learning achievement in terms of and increase the capacity and capability creative thinking. Ability to think creative class experiments, including in category is while control classes include category rendah. 2 increase the capacity and capability) there are differences between the students think creatively mathematical ability, is low, and who got a lesson generative, 3) Mathematical Disposition students attending mathematics lessons 
by learning generative better than students who follow in mathematics teaching conventional, this mathematical disposition students in the class experiments, including in category, while in control classes this mathematical disposition including in category is low. 4) There is interaction between models in teaching and skill level early students in producing creative ability to think. 5) There is the association between ability to think creatively mathematical with Disposition, mathematical category association.

Key words : Learning Generative, Creative Thinking, Mathematical Disposition

\section{Pendahuluan}

Aktivitas manusia tidak dapat dipisahkan dengan kegiatan berpikir. Kegiatan berpikir salah satunya adalah pada saat memecahkan persoalan atau menentukan strategi yang tepat dalam mengambil suatu keputusan. Kemampuan berpikir harus dikembangkan salah satunya melalui kegiatan pembelajaran di sekolah. Menurut Sizer (Johnson, 2011:181) "Sekolah artinya belajar menggunakan pikiran dengan baik, berpikir kreatif menghadapi persoalan-persoalan penting, serta menanamkan kebiasaan untuk berpikir"'.

Kemampuan berpikir kreatif siswa tidak dapat berkembang dengan baik apabila dalam proses pembelajaran guru tidak melibatkan siswa secara aktif dalam pembentukan konsep, metode pembelajaran yang digunakan di sekolah masih secara konvensional, yaitu pembelajaran yang masih berpusat pada guru. Pembelajaran tersebut dapat menghambat perkembangan kreatifitas dan aktifitas siswa seperti dalam hal mengkomunikasikan ide dan gagasan. Sehingga keadaan ini tidak lagi sesuai dengan target dan tujuan pembelajaran matematika. Tujuan pembelajaran akan tercapai apabila perencanaan dan metode yang digunakan dapat mempengaruhi potensi dan kemampuan yang dimiliki peserta didik dan keberhasilan tersebut akan tercapai apabila peserta didik dilibatkan dalam proses berpikirnya.

Hasil penelitian Khabibah (2009) pada siswa SMP kelas VII, berdasarkan analisis data yang dilakukan (a) Pada LAS 1, hanya sebanyak 10 siswa dari 38 siswa, yaitu sekitar 26,3\% siswa yang mampu membuat cerita yang berbeda. Hal ini menunjukkan bahwa kreativitas siswa rendah. (b) $100 \%$ siswa bisa memenuhi permintaan dari LAS 2. Hal ini menunjukkan bahwa siswa sudah terbiasa dengan soal terbuka, sehingga kreativitas siswa sudah mulai meningkat. (c) Pada LAS 3, sebanyak 34 siswa dari 38 siswa, yaitu sekitar 89,5\% siswa sudah menunjukkan kreativitasnya dalam menemukan persamaan linier satu variabel serta menyebutkan komponen-komponenya.(d) Sebanyak 32 siswa dari 38 siswa atau sekitar 84,2\% siswa telah kreatif. (e) Sebagian besar siswa mengalami peningkatan kreativitas. Hal ini tampak dari hasil pengerjaan LAS 5a (iv) ke LAS 5b (i), yaitu sebanyak 34 siswa dari 36 siswa, atau sekitar 94,4 \% siswa menunjukkan hasil yang cukup baik pada saat mengerjakan LAS 5b. Berdasar pada pembahasan di atas, menunjukkan bahwa kreativitas siswa kelas VII SMP dalam menyelesaikan soal terbuka cukup tinggi. 
Data di atas menunjukkan bahwa prestasi belajar matematika siswa tergolong rendah atau kemampuan berpikir kreatif siswa SMP/ MTs berada pada kategori rendah. Kenyataan lainnya ketika siswa diberikan permasalahan berupa soal-soal berpikir tingkat tinggi siswa enggan untuk mengerjakannya bahkan ia menyerah terlebih dahulu sebelum mencoba menyelesaikan soal tersebut. Siswa kurang termotivasi untuk belajar, perhatian siswa terhadap hasil belajar atau nilai yang diperoleh siswa terkesan menerima apa adanya dan "pasrah" bahkan ketika mendapatkan nilai di bawah kriteria ketuntasan minimalpun siswa tersebut tidak mau untuk melakukan perbaikan.

Rendahnya sikap positif siswa terhadap matematika, rasa percaya diri dan keingintahuan siswa berdampak pada hasil pembelajaran yang rendah. Hal tersebut senada dengan yang dikemukakan oleh Syaban (2009:113) "Pada saat ini, daya dan disposisi matematis siswa belum tercapai sepenuhnya". Hal tersebut antara lain karena pembelajaran cenderung berpusat pada guru yang menekankan pada proses prosedural, tugas latihan yang mekanistik, dan kurang memberi peluang kepada siswa untuk mengembangkan kemampuan berpikir matematis. Untuk meningkatkan disposisi matematik, guru harus mampu memberikan pengalaman belajar matematik yang baik pada siswa. Disposisi matematis siswa tidak akan tumbuh dan berkembang dalam lingkungan pembelajaran yang disetting agar siswa hanya duduk dengan manis untuk mendengar dan menerima informasi dari guru. Hal lain yang perlu disampaikan pada siswa adalah jika siswa mengabaikan disposisi maka dapat merugikan dirinya dalam belajar.

Faktor lain yang menyebabkan kurang berhasilnya pembelajaran matematika adalah keaktifan siswa. Metode konvensional yang banyak dijumpai dalam pembelajaran mengakibatkan siswa pasif karena sebagian besar proses pembelajaran didominasi oleh guru, siswa hanya mendengarkan dan mencatat yang pokok dari penyampaian guru sehingga keaktifan siswa dalam mengikuti proses pembelajaran hampir tidak ada. Siswa dikatakan belajar aktif jika ada mobilitas, misalnya nampak dari interaksi yang terjadi antara guru dan siswa, antara siswa itu sendiri. Komunikasi yang terjadi tidak hanya satu arah dari guru ke siswa tetapi banyak arah (Krismanto, 2003:1). Dalam pengajaran matematika diharapkan siswa benar-benar aktif sehingga akan berdampak pada ingatan siswa tentang apa yang dipelajari akan lebih lama bertahan. Suatu konsep mudah dipahami dan diingat oleh siswa bila konsep tersebut disajikan melalui prosedur dan langkah-langkah yang tepat, jelas dan menarik. Pada dasarnya, semua siswa memiliki potensi untuk mencapai kompetensi. Jika sampai mereka tidak mencapai kompetensi, bukan karena mereka tidak memiliki kemampuan untuk itu, tetapi lebih banyak karena mereka tidak disediakan pengalaman belajar yang relevan dengan keunikan masing-masing karakteristik individual (Muslich, 2008: 64). Disposisi matematik merupakan salah satu faktor penunjang keberhasilan belajar matematika siswa. Siswa memerlukan disposisi matematik untuk bertahan dalam menghadapi masalah, mengambil tanggung jawab 
dan membiasakan kerja yang baik dalam matematika (Mahmudi, 2010: 5). Sikap dan kebiasaan berpikir yang baik pada hakekatnya akan membentuk dan menumbuhkan disposisi matematis (mathematical disposition).

Upaya untuk meningkatkan kemampuan berpikir kreatif dan disposisi matematik dengan menciptakan pembelajaran matematika yang inovatif, melibatkan aspek kognitif, afektif dan psikomotor. Agar dapat lebih mengoptimalkan kemampuan berpikir kreatif matematik siswa, guru dapat merancang proses pembelajaran yang melibatkan siswa secara aktif. Guru melibatkan aktifitas aktif siswa selama proses belajar mengajar dan menciptakan materi ajar yang memiliki pertanyaan divergen. Alternatif solusi yang dapat mengatasi permasalahan dalam pendidikan matematika ini adalah dengan meningkatkan baik kuantitas maupun kualitas pembelajaran melalui pembelajaran generatif. Melalui pembelajaran generatif aktifitas siswa dalam belajar lebih terfasilitasi. Dalam pembelajaran generatif siswa tidak hanya menghapal rumus dan mengerjakan latihan saja, akan tetapi siswa dituntut dan dibiasakan untuk memahami konsep dan membangun pemahamannya sendiri, siswa kreatif dalam mencari alternatif solusi dalam pemecahan masalah, siswa juga harus mampu menerapkan matematika untuk memecahkan masalah yang berhubungan dengan kehidupan mereka sehari-hari. Untuk itu, perlu upaya inovatif mengembangkan model-model pembelajaran yang dapat mengakomodir tuntutan kurikulum matematika tahun 2006. Model pembelajaran yang dapat menumbuhkembangkan hal tersebut di atas adalah model pembelajaran yang didesain menurut pandangan konstruktivisme. Pembelajaran menurut pandangan konstruktivisme bertujuan membantu siswa untuk membangun konsepkonsep/prinsip-prinsip matematika dengan kemampuannya sendiri melalui proses asimilasi dan akomodasi.

Menurut Osborne dan Wittrock (dalam Hulukati, 2005) bahwa esensi pembelajaran generatif adalah pikiran atau otak manusia bukanlah penerima informasi secara pasif tetapi aktif mengkonstruksi dan menafsirkan informasi dan selanjutnya menarik kesimpulan berdasarkan informasi itu. Pembelajaran generatif melibatkan aktivitas mental berpikir. Mental berpikir seseorang yang melakukan pembelajaran generatif akan berkembang sejalan dengan proses belajarnya. Pandangan lain tentang pembelajaran generatif oleh Wimberg dan Hollins (2002) adalah pada aspek teoritis pembelajaran generatif terkait erat dengan konstruktivisme, strategi pembelajaran yang mirip dengan pembelajaran kooperatif, menjelajahi perspektif, membangun pengetahuan di atas pengetahuan sebelumnya, secara aktif menghasilkan empat elemen ide-ide yaitu: ingat, integrasi, organisasi, dan elaborasi. Sedangkan dari aspek praktis terdiri dari Brainstorm, menghasilkan sub-masalah, sub-tujuan, dan strategi untuk mencapai tugas atau masalah yang lebih tinggi, dan membangun model mental atau mind mapping.

Berdasar pada latar belakang masalah di atas maka rumusan masalah dalam penelitian ini adalah : 1. Apakah peningkatan kemampuan berpikir kreatif siswa 
yang mengikuti pembelajaran generatif lebih baik daripada siswa yang mengikuti pembelajaran matematika secara konvensional? 2. Apakah terdapat perbedaan peningkatan kemampuan berpikir kreatif matematik antara siswa kemampuan tinggi, sedang, dan rendah yang mendapat pembelajaran generatif ? 3. Apakah disposisi matematik siswa yang mengikuti pembelajaran matematika melalui pembelajaran generatif lebih baik daripada siswa yang mengikuti pembelajaran matematika secara konvensional? 4. Apakah terdapat interaksi antara model pembelajaran dan tingkat kemampuan awal siswa dalam menghasilkan kemampuan berpikir kreatif? 5.Apakah terdapat asosiasi antara kemampuan berpikir kreatif matematik dengan disposisi matematik?

\section{Metode Penelitian}

Penelitian ini merupakan penelitian kuasi eksperimen dengan disain kelompok kontrol tidak ekivalen karena tidak adanya pengacakan dalam menentukan subjek penelitian, peneliti tidak membentuk kelas baru berdasarkan pemilihan sampel secara acak. Penelitian ini melibatkan dua kategori kelas sampel, yaitu kelas eksperimen dan kelas kontrol. Kelas-kelas sampel tersebut tidak dibentuk dengan cara menempatkan secara acak subjek-subjek penelitian ke dalam kelas-kelas sampel tersebut, melainkan menggunakan kelas-kelas yang ada. Di kelas eksperimen dan kelas kontrol berturut-turut dilaksanakan pembelajaran generatif (X) dan pembelajaran konvensional. Dengan demikian disain penelitian ini adalah sebagai berikut:
O $\quad \mathrm{X} \quad \mathrm{O}$
$\mathrm{O} \quad \mathrm{O}$

dengan: $\mathrm{O}=$ pretes / postes berpikir kreatif matematik

$\mathrm{X}=$ model pembelajaran generatif

\section{Subjek Penelitian}

Populasi dalam penelitian ini adalah siswa kelas VII Madrasah Tsanawiyah Negeri (MTsN) Cikembar yang berada di Kabupaten Sukabumi. Populasi ini dipilih dengan pertimbangan bahwa siswa kelas VII baru mengenal lingkungan dan iklim belajar di MTs masih dalam masa transisi dalam mengenal lingkungan belajar yang baru, dan dinilai telah memiliki kemampuan dasar matematika relatif lebih homogen. Pemilihan sampel penelitian menggunakan teknik purposive sampling. Peneliti menentukan sendiri sampel yang diambil berdasarkan pertimbangan tertentu. Sampel yang diambil dalam penelitian ini sebanyak dua kelas, satu kelas dijadikan kelas eksperimen dan satu kelas dijadikan kelas kontrol. Pada kelas eksperimen dilaksanakan pembelajaran matematika dengan pembelajaran generatif, sedangkan pada kelas kontrol dilaksanakan pembelajaran matematika dengan menggunakan pendekatan konvensional. 


\section{Instrumen Penelitian}

Instrumen yang digunakan dalam penelitian ini terdiri dari tes dan non tes. Instrumen tes adalah tes kemampuan berpikir kreatif matematik. Sementara itu, instrumen non tes meliputi: skala disposisi matematik, jurnal siswa, dan pedoman observasi (diberikan untuk kelas eksperimen)

\section{Hipotesis Penelitian}

Berdasarkan rumusan masalah sebelumnya, hipotesis penelitian sebagai berikut:

1. Peningkatan kemampuan berpikir kreatif siswa yang mengikuti pembelajaran generatif lebih baik daripada siswa yang mengikuti pembelajaran matematika secara konvensional.

2. Terdapat peningkatan kemampuan berpikir kreatif matematik antara siswa kemampuan tinggi, sedang, dan rendah yang mendapat pembelajaran generatif.

3. Disposisi matematik siswa yang mengikuti pembelajaran matematika melalui pembelajaran generatif lebih baik daripada siswa yang mengikuti pembelajaran matematika secara konvensional.

4. Terdapat interaksi antara model pembelajaran dan tingkat kemampuan awal siswa dalam menghasilkan kemampuan berpikir kreatif

5. Terdapat asosiasi antara kemampuan berpikir kreatif matematik dengan disposisi matematik.

\section{Hasil Penelitian}

Berdasarkan pengolahan data pretes, postes, dan gain ternormalisasi kemampuan berpikir kreatif matematis, diperoleh skor rerata dan deviasi standar $(s)$.

Tabel 1

Statistik Deskriptif Skor Pretes, Postes, dan Gain Ternormalisasi Kemampuan Berpikir Kreatif Matematis

\begin{tabular}{|c|c|c|c|c|c|c|c|}
\cline { 3 - 8 } \multicolumn{2}{c|}{} & \multicolumn{3}{c|}{ Pembelajaran Generatif } & \multicolumn{2}{c|}{ Pembelajaran Konvensional } \\
\hline \multirow{2}{*}{ Hasil } & Pretes & Postes & $\begin{array}{c}\text { Gain } \\
\text { Ternormalis } \\
\text { asi }\end{array}$ & Pretes & Postes & $\begin{array}{c}\text { Gain } \\
\text { Ternormalis } \\
\text { asi }\end{array}$ \\
\hline \multirow{3}{*}{$\begin{array}{c}\text { Berpikir } \\
\text { Kreatif }\end{array}$} & $\bar{X}$ & 15,56 & 25,03 & 0,4 & 13,86 & 20,48 & 0,2 \\
\cline { 2 - 8 } & $S$ & 3,02 & 5,53 & 3,57 & 2,85 & 3,77 & 2,28 \\
\cline { 2 - 8 } & $X$ min & 9 & 13 & 1 & 9 & 13 & 2 \\
\cline { 2 - 8 } & $X$ & 22 & 38 & 19 & 21 & 29 & 12 \\
\hline
\end{tabular}

Keterangan : Skor ideal tes berpikir kreatif matematis $=42$ 
Berdasarkan tabel1 di atas, rerata pretes pada kelas eksperimen 15,56 dan pada kelas kontrol 13,86 atau berdasarkan rerata persentase pretes kemampuan berpikir kreatif matematis $38 \%$ pada kelas eksperimen dan 34\% kelas kontrol, kategori kemampuan berpikir kreatif kedua kelas termasuk rendah. Hasil postes menunjukkan perbedaan nilai rerata postes kelas eksperimen 25,03 dengan rerata persentase sebesar $61 \%$ termasuk pada kategori cukup sedangkan pada kelas kontrol nilai rerata postes 20,48 dengan rerata persentase sebesar 50\% termasuk pada kategori kurang.

Berdasarkan hasil deskriptif kemampuan berpikir kreatif matematis siswa dari persentase setiap skor pada tiap indikator terhadap skor total kemudian dikualifikasikan kualitas kemampuan berpikir kreatif diperoleh hasil sebagai berikut: hasil pretes pada kelas eksperimen sebanyak 35 siswa termasuk pada kategori kurang kreatif, selanjutnya postes diperoleh hasil sebagai berikut: 8 siswa kurang kreatif, 22 siswa cukup kreatif, 4 siswa kreatifnya baik dan 1 siswa kreatifnya sangat baik. Kualitas kemampuan berpikir kreatif pretes pada kelas kontrol diperoleh hasil sebagai berikut 37 siswa termasuk pada kategori kurang kreatif. Hasil postes kelas kontrol sebagai berikut: 26 siswa kurang kreatif, 11 siswa cukup kreatif dan tidak ada siswa kategori sangat baik dan baik kreatifnya. Hasil tersebut menunjukkan bahwa siswa yang memperoleh pembelajaran generatif memiliki peningkatan jumlah siswa yang memenuhi kategori kreatif, hanya 8 siswa yang masih kurang kreatif ini disebabkan siswa tersebut tidak menyenangi matematika dan kurang berusaha untuk meningkatkan kemampuan berpikir kreatifnya, minat dan kegigihan untuk belajar matematikanya kurang. Peningkatan kemampuan berpikir kreatif matematis siswa yang memperoleh pembelajaran generatif lebih baik dibanding peningkatan kemampuan berpikir kreatif matematis siswa yang memperoleh pendekatan konvensional.

Kemampuan berpikir kreatif matematis siswa yang memperoleh pembelajaran generatif lebih baik dibanding kemampuan berpikir kreatif matematis siswa yang memperoleh pembelajaran konvensional, ditinjau dari pencapaian hasil belajar, dan peningkatan kemampuan berpikir kreatif matematis. Asumsi tersebut perlu dibuktikan kebenarannya dengan menggunakan perhitungan statistik. Sebelum dilakukan pengujian secara statistik, terlebih dahulu dilakukan uji normalitas dan homogenitas varians rerata skor postes, dan gain ternormalisasi kemampuan berpikir kreatif matematis kedua kelas sampel.

Untuk mengetahui tingkat kreativitas siswa, jawaban siswa dikategorikan kreatif apabila siswa menjawab benar pada ketiga indikator (kelancaran, keaslian, dan keluwesan). Cukup apabila menjawab dua atau satu indikator dan rendah apabila tidak menjawab. Dari hasil perhitungan pretes pada kelas eksperimen diperoleh siswa dengan kreatif tinggi sebesar $2,86 \%$, cukup $25,1 \%$, dan rendah $71,43 \%$ sedangkan postes hasilnya menjadi $68,57 \%$ siswa dengan kreatif tinggi, $17,14 \%$ cukup dan $14,29 \%$ rendah. Hal ini menunjukkan bahwa terjadi peningkatan berpikir kreatif matematis siswa pada kelas eksperimen. Pada kelas kontrol 
diperoleh data persentase jumlah siswa kreatif sebagai berikut: tinggi $0 \%$, cukup 21,63 , dan rendah $78,37 \%$ sedangkan postes hasilnya menjadi $24,32 \%$ tinggi, $56,75 \%$ cukup dan $18,93 \%$ rendah hal ini menunjukkan bahwa terjadi peningkatan berpikir kreatif matematis siswa pada kelas eksperimen dan kelas kontrol namun pada kelas eksperimen peningkatannya lebih baik dibanding pada kelas eksperimen. Persentase kemampuan berpikir kreatif matematis berdasarkan tiap indikator disajikan pada Tabel sebagai berikut:

Tabel 2 Kemampuan Berpikir Kreatif Matematik berdasarkan Tiap Indikator

\begin{tabular}{|c|c|c|c|c|}
\hline & \multicolumn{4}{|c|}{ Indikator } \\
\hline & Keaslian & Kelancaran & Keluwesan & Kepekaan \\
\hline \multicolumn{5}{|c|}{ Kelas Eksperimen } \\
\hline Pretes & $50 \%(\mathrm{~K})$ & $34 \%(\mathrm{SK})$ & $34 \%(\mathrm{SK})$ & $46 \%(\mathrm{~K})$ \\
\hline Postes & $71 \%(\mathrm{C})$ & $56 \%(\mathrm{C})$ & $58 \%(\mathrm{C})$ & $75 \%$ (B) \\
\hline \multicolumn{5}{|c|}{ Kelas Kontrol } \\
\hline Pretes & $38 \%(\mathrm{SK})$ & $34 \%(\mathrm{SK})$ & $34 \%(\mathrm{SK})$ & $48 \%(\mathrm{~K})$ \\
\hline Postes & $56 \%(C)$ & $54 \%(\mathrm{~K})$ & $51 \%(\mathrm{~K})$ & $65 \%(C)$ \\
\hline
\end{tabular}

Berdasarkan Tabel di atas, tiap indikator menunjukkan adanya peningkatan kemampuan berpikir kreatif matematis baik pada kelas eksperimen maupun pada kelas kontrol. Pada kelas eksperimen yang pembelajarannya dengan pembelajaran generatif, hasil pretes ke empat indikator berpikir kreatif matematis, dua sangat kurang dan dua kurang kreatif tetapi pada hasil postes menunjukkan adanya peningkatan tiga indikator termasuk pada kategori cukup, dan satu indikator yaitu kepekaan termasuk pada kategori baik. Pada kelas kontrol yang pembelajarannya dengan konvensional, hasil pretes kemampuan berpikir kreatif matematis ke empat indikator berpikir kreatif matematis termasuk pada kategori tiga sangat kurang dan satu kurang. Hasil postes terdapat dua indikator yaitu kelancaran dan keluwesan pada kategori kurang hanya dua indikator yaitu keaslian dan kepekaan termasuk pada kategori cukup. Dari data tersebut dapat disimpulkan bahwa pembelajaran generatif mampu meningkatkan kemampuan berpikir kreatif matematis meskipun pada kategori cukup.

Untuk mengetahui peningkatan kemampuan berpikir kreatif berdasarkan kemampuan matematis tinggi, sedang, dan rendah, setelah data dikelompokkan menjadi tiga kategori yaitu kelompok tinggi, sedang dan rendah pada siswa yang mengikuti pembelajaran generatif. Untuk mengetahui perbedaan peningkatan kemampuan berpikir kreatif matematis ketiga kelompok pada kelas eksperimen terlebih dahulu diuji normalitas dan homogenitasnya. Adapun kemampuan berpikir kreatif matematis siswa berdasarkan kelompok disajikan sebagai berikut: 
Tabel 3

Deskripsi Kemampuan Berpikir Kreatif Matematis berdasarkan Kemampuan Awal Matematik

\begin{tabular}{|c|l|l|l|l|l|l|l|}
\hline \multirow{2}{*}{$\begin{array}{c}\text { Data } \\
\text { Statistik }\end{array}$} & \multirow{2}{*}{ Kategori } & \multicolumn{3}{|c|}{ Eksperimen } & \multicolumn{3}{c|}{ Kontrol } \\
\cline { 2 - 8 } & & Pretes & Postes & N-gain & Pretes & Postes & N-gain \\
\hline \multirow{3}{*}{ Rerata } & Tinggi & 16,81 & 29,82 & 0,51 & 14,38 & 23,23 & 0,32 \\
\cline { 2 - 8 } & Sedang & 15,69 & 24,94 & 0,35 & 13,69 & 20,30 & 0,24 \\
\cline { 2 - 8 } & Rendah & 14 & 18,5 & 0,16 & 13.45 & 17,45 & 0,16 \\
\hline \multirow{2}{*}{$\begin{array}{c}\text { Standar } \\
\text { Deviasi }\end{array}$} & Tinggi & 2,4 & 3,37 & 0,11 & 2,57 & 2,62 & 0,045 \\
\cline { 2 - 8 } & Sedang & 2,12 & 2,43 & 0,051 & 2,59 & 2,84 & 0,049 \\
\cline { 2 - 8 } & Rendah & 4,59 & 5,50 & 0,10 & 3,56 & 3,64 & 0,052 \\
\hline
\end{tabular}

Dari tabel tersebut diketahui bahwa siswa yang pembelajarannya melalui pembelajaran generatif skor gain ternormalisasi kemampuan berpikir kreatif matematis siswa kelompok tinggi kategori gain ternormalisasinya adalah 0,51 masuk kategori sedang, kelompok sedang kategori gain ternormalisasinya adalah 0,35 masuk kategori sedang, dan kelompok rendah kategori gain ternormalisasinya adalah 0,16 masuk kategori rendah dari skor maksimum ideal 1,00. Siswa yang pembelajarannya melalui pembelajaran konvensional skor gain kemampuan berpikir kreatif matematis siswa kelompok tinggi kategori gain ternormalisasinya adalah 0,32 masuk kategori sedang, kelompok sedang kategori gain ternormalisasinya adalah 0,24 masuk kategori rendah, dan kelompok rendah kategori gain ternormalisasinya adalah 0,16 masuk kategori rendah dari skor maksimum ideal 1,00. Dari data tersebut dapat disimpulkan bahwa kelompok tinggi dan sedang yang pembelajarannya dengan pembelajaran generatif termasuk pada kategori sedang, sedangkan pada kelas kontrol hanya kelompok tinggi saja yang masuk kategori sedang. Kemampuan berpikir kreatif matematis kelas eksperimen berbeda secara signifikan bila ditinjau dari kemampuan awal matematik, sehingga dapat disimpulkan pembelajaran generatif lebih cocok digunakan untuk siswa dalam kategori tinggi saja, kategori rendah sedang, atau kategori rendah saja untuk dapat meningkatkan kemampuan berpikir kreatif matematik.

Untuk memperlihatkan signifikan perbedaan rerata disposisi matematik antara siswa kelas eksperimen dan siswa kelas kontrol diuji dengan menggunakan uji perbedaan rerata disposisi matematik. Uji perbedaan rerata pretes kemampuan disposisi matematik kedua kelas sampel menggunakan uji -t, karena kedua kelas sampel berdistribusi normal dan homogen. Hipotesisnya sebagai berikut:

$$
\mathrm{H}_{0}: \mu_{1}=\mu_{2}
$$

Disposisi matematik siswa yang mendapat pembelajaran generatif sama dengan disposisi matematik siswa yang mendapatkan pembelajaran konvensional.

$$
\mathrm{H}_{1}: \mu_{1}>\mu_{2}
$$


Disposisi matematik siswa yang mengikuti pembelajaran generatif lebih baik daripada siswa yang mengikuti pembelajaran matematika secara konvensional . Hipotesis statistik tersebut merupakan hipotesis satu arah, sehingga kriteria pengujiannya sebagai berikut: Jika $\frac{1}{2} \operatorname{sig} .(2-$ tailed $)=\operatorname{sig} .(1-$ tailed $)>0,05$, $\mathrm{H}_{0}$ diterima.

Tabel 4

Hasil Uji Signifikansi Perbedaan Rerata Skala Disposisi Matematik

\begin{tabular}{|l|l|r|r|r|r|}
\hline & \multicolumn{2}{|c|}{$\begin{array}{c}\text { t-test for Equality } \\
\text { of Means }\end{array}$} & & & \\
\hline & $\mathrm{T}$ & df & $\begin{array}{c}\text { Sig. (2- } \\
\text { tailed) }\end{array}$ & $\begin{array}{c}\text { Mean } \\
\text { Difference }\end{array}$ \\
\hline $\begin{array}{l}\text { Disposisi } \\
\text { matematik }\end{array}$ & $\begin{array}{l}\text { Equal } \\
\text { variansces } \\
\text { assumed }\end{array}$ & 14.864 & 70 & .000 & 25.32120 \\
\hline
\end{tabular}

Berdasarkan hasil perhitungan di atas, diperoleh nilai $\frac{1}{2} \operatorname{sig} .(2-$ tailed $)=0$ sehingga kesimpulannya $\mathrm{H}_{0}$ ditolak atau $\mathrm{H}_{1}$ diterima secara signifikan dengan kata lain disposisi matematik siswa yang mengikuti pembelajaran generatif lebih baik daripada siswa yang mengikuti pembelajaran matematika secara konvensional.

Untuk mengetahui adanya asosiasi antara kemampuan berpikir kreatif matematis dengan disposisi matematik, hipotesis penelitian yang diuji sebagai berikut:

$\mathbf{H}_{0}=$ Tidak terdapat asosiasi yang signifikan antara kemampuan berpikir kreatif matematis dengan disposisi matematik.

$\mathbf{H}_{1}=$ Terdapat asosiasi yang signifikan antara kemampuan berpikir kreatif matematis dengan disposisi matematik.

Dari Tabel di atas nilai signifikansi $0,000<0,050$, kesimpulannya $\mathrm{H}_{0}$ ditolak. Jadi, dapat disimpulkan bahwa terdapat asosiasi yang signifikan antara kemampuan berpikir kreatif matematis dengan disposisi matematik. Besarnya korelasi antara disposisi matematik dengan kemampuan berpikir kreatif 0,068 termasuk korelasi tinggi.

Pengujian terhadap Interaksi Model Pembelajaran dan Tingkat Kemampuan Awal Siswa

$\mathrm{H}_{0}=$ Tidak ada perbedaan rerata kemampuan berpikir kreatif matematis antara pembelajaran generatif dari TKAS dengan pembelajaran konvensional dari TKAS. 
$\mathrm{H}_{1}=$ Terdapat perbedaan rerata kemampuan berpikir kreatif matematis antara pembelajaran generatif dari TKAS dengan pembelajaran konvensional dari TKAS.

Kriteria pengujian: jika signifikansi $>0,05$, maka $\mathrm{H}_{0}$ diterima, atau jika signifikansi $<0,05$, maka $\mathrm{H}_{0}$ ditolak. Dari Tabel di atas nilai signifikansi $\quad 0,031<0,050$, kesimpulannya $\mathrm{H}_{0}$ ditolak. Kesimpulannya terdapat perbedaan rerata kemampuan berpikir kreatif matematis antara pembelajaran generatif dari TKAS dengan pembelajaran konvensional dari TKAS. Jadi terdapat interaksi antara model pembelajaran dan TKAS dalam menghasilkan kemampuan berpikir kreatif matematik.

\section{Kesimpulan dan Saran}

\section{Kesimpulan}

Berdasarkan hasil analisis dan pembahasan pada keseluruhan tahap penelitian yang telah dilakukan, diperoleh beberapa kesimpulan yang berkaitan dengan meningkatkan kemampuan berpikir kreatif dan disposisi matematik siswa madrasah Tsanawiyah melalui pembelajaran generatif sebagai berikut:

1. Peningkatan kemampuan berpikir kreatif siswa yang mengikuti pembelajaran generatif lebih baik daripada siswa yang mengikuti pembelajaran matematika secara konvensional. Kemampuan berpikir kreatif matematis siswa kelas eksperimen termasuk pada kategori sedang sedangkan kelas kontrol termasuk kategori rendah.

2. Terdapat perbedaan peningkatan kemampuan berpikir kreatif matematik antara siswa kemampuan tinggi, sedang, dan rendah yang mendapat pembelajaran generatif.

3. Disposisi matematik siswa yang mengikuti pembelajaran matematika melalui pembelajaran generatif lebih baik daripada siswa yang mengikuti pembelajaran matematika secara konvensional. Disposisi matematik kelas eksperimen termasuk pada kategori sedang sedangkan kelas kontrol termasuk kategori sangat rendah.

4. Terdapat interaksi antara model pembelajaran dan tingkat kemampuan awal siswa dalam menghasilkan kemampuan berpikir kreatif.

5. Terdapat asosiasi antara kemampuan berpikir kreatif matematik dengan disposisi matematik. Kategori asosiasi antara kemampuan berpikir kreatif matematik dengan disposisi matematik termasuk pada kategori tinggi sebesar 0,68.

\section{Saran}

Berdasarkan pada hasil analisis data, pembahasan, dan kesimpulan dalam penelitian ini, penulis memberikan saran sebagai berikut: 
1. Guru matematika hendaknya menerapkan model pembelajaran generatif sebagai salah satu alternatif dalam meningkatkan kemampuan berpikir kreatif dan disposisi matematik khususnya dan kemampuan matematik pada umumnya.

2. Untuk topik matematika, pembelajaran matematika menggunakan model pembelajaran generatif membutuhkan waktu lebih lama dari pembelajaran konvensional. Jadi, disarankan pembelajaran matematika menggunakan model pembelajaran generatif diterapkan pada topik-topik matematika yang esensial, sehingga konsep topik-topik ini dapat lebih dipahami secara mendalam.

3. Para peneliti selanjutnya kiranya dapat menerapkan model pembelajaran generatif pada pokok bahasan yang lain, mengungkap perbedaan kemampuan berpikir kreatif pada kelas kontrol, meningkatkan kemampuan berpikir kreatif dan disposisi matematik khususnya bagi siswa yang berpikir kreatifnya dan disposisi matematiknya rendah, serta mengembangkan aspek kemampuan yang lain seperti penalaran, pemecahan masalah, kemampuan koneksi matematik dan kemampuan matematik lainnya.

\section{DAFTAR PUSTAKA}

Grabowski, Lee, \& Lim. (2004)."Generative Learning: Principles and Implications for Making Meaning”. [online] tersedia .www.faculty.ksu.edu.sa/.../ER5849x_C010.fm.diunduh 12 Desember 2012.

Hidayat, W. (2011).Meningkatkan Kemampuan Berpikir Kritis dan Kreatif Matematik Siswa Melalui Pembelajaran Kooperatif Think-Talk-Write (TTW).Bandung: Tesis pada SPS UPI: TidakDiterbitkan

Hulukati, E. (2005). Mengembangkan Kemampuan Komunikasi dan Pemecahan Masalah Matematis Siswa SMP Melalui Model Pembelajaran Generatif. Bandung: Disertasi PPS UPI tidak diterbitkan.

Johnson, E. B. (2011). Contextual Teaching and Learning. Bandung: Kaifa.

Khabibah, S. (2009). "Kreatifitas Siswa Kelas VII SMP dalam Menyelesaikan Soal Terbuka". Jurnal Pendidikan Matematika dan Sains Universitas Negeri Surabaya Edisi : volume 16 No 1, Juni 2009

Krismanto, Al. (2003). "Beberapa Teknik, Model, dan Strategi dalam Pembelajaran Matematika". Makalah disampaikan pada pelatihan Instruktur/Pengembang SMU 28 Juli s.d. 10 Agusutus 2003. Yogyakarta: PPPG Matematika.

Mahmudi, A. (2010). "Mengukur Kemampuan Berpikir Kreatif Matematis".Makalah Disajikan Pada Konferensi Nasional Matematika XV UNIMA Manado, 30 Juni 3 Juli 2010.

Munandar, S.C. U. (1999). Mengembangkan Bakat dan Kreativitas Anak Sekolah Petunjuk Bagi Para Guru dan Orang Tua. Jakarta: PT. Gramedia Widiasarana Indonesia.

Muslich, M. (2008). KTSP Dasar Pemahaman dan Pengembangan. Jakarta. PT. Bumi Aksara. 
Noer, S. H. (2011).Peningkatan Kemampuan Berpikir Kritis, Kreatif, dan Reflektif $(K 2 R)$ Matematis Siswa SMP Melalui Pembelajaran Berbasis Masalah. Disertasi pada SPS UPI: Tidak Diterbitkan.

Philippou, G. \& Nicolaidou, M. (2004) “Attitudes Toward Mathematics, Self Efficacy and Achievment in Problem Solving”. Jurnal: ERME, CERME-3, TG-2.

Polking, J. (1998). Response To NCTM's Round 4 Questions. [Online] Tersedia: pada http://www.ams.org/government/argrpt4.html. Diunduh pada 12 Januari 2012.

Sagala, S. (2010). Konsep dan Makna Pembelajaran. Bandung: Alfabeta

Schloglmann, W.(2004) "Meta Affect And Strategies In Mathematics Learning”.Journal ERME-CERME-4. Austria: University of Linz.

Siswono, T.Y.E. (2004). "Mendorong Berpikir Kreatif Siswa melalui Pengajuan Masalah Problem Posing”. Makalah disajikan dalam Konferensi Himpunan Matematika Indonesia di Denpasar, Bali. 23-27 Juli 2004

Syaban, M. (2009). "Menumbuhkembangkan Daya dan Disposisi Matematis Siswa Sekolah Menengah Atas Melalui Pembelajaran Investigasi”. Jurnal Educationist Vol. III No. 2 Juli 2009.

Syahputra, E.(2011). Peningkatan Kemampuan Spasial dan Disposisi Matematis Siswa SMP dengan Pendekatan PMRI pada Pembelajaran Geometri Berbantuan Komputer. Disertasi pada SPS UPI: Tidak Diterbitkan 